\title{
THE STRATEGY FOR HANDLING CORRUPTION'S CRIMINAL ACTION RELATIONSHIP TO SAVING OF STATE FINANCIAL LOSSES
}

\author{
Bambang Tri Bawono \\ Sultan Agung Islamic University \\ bambang@unissula.ac.id
}

\begin{abstract}
The massive amount of corruption that has occurred so far is closely related to the increase in state financial losses. Even though there are regulations regarding additional penalties in the form of compensation money as regulated in Article 18 of the Corruption Crime Law, the existence of this provision has not been able to return the overall state financial losses, even the total state financial losses with those saved have a significant difference. Based on this, this study examines the factors that cause state financial losses in the criminal act of corruption. Apart from that, strategies must be taken to recover from losses to state finances. The research method used in this research is library research with a normative juridical approach. The results of this study indicate that the provision of additional penalties in the form of replacement money as contained in Article 18 of the Corruption Eradication Law is basically suitable for recovering state financial losses. It's just that, the existence of such additional crimes because it is accompanied by law enforcement with a retributive justice approach which results in the crime of substitute money which cannot recover state financial losses, because the retributive justice approach requires expensive costs.
\end{abstract}

Keywords: Corruption; Rescue of State Financial Losses; Retributive Justice Approach.

\section{A. INTRODUCTION}

Indonesia was idealized and aspired by the founding fathers as a rule of law (Rechtsstaat). The 1945 constitution Article 1 paragraph (3) states that "the State of Indonesia is a State of Law". Therefore, the law should be understood and developed as a unified system. Moreover, the state is to be understood as a legal concept, namely as a rule of law. ${ }^{1}$

Law enforcement efforts to eradicate corruption in Indonesia have been going on for a long time since the 1960s. Although changes in legislation have been made several times and most recently changed to Act No. 20 of 2001 Amendment to Act No. 31 of 1999 concerning the Eradication of Corruption Crimes, but the changes in legislation have not been able to reduce the criminal acts of corruption that have occurred. ${ }^{2}$ The

1 Jawade Hafidz, Agung Widodo, Pelanggaran Perpres Nomor 54 Tahun 2010 Tentang Pengadaan Barang Dan Jasa Pemerintah Oleh Penyedia Barang Dan Jasa Atau Pengguna Jasa Dalam Perspektif Tindak Pidana Korupsi, Jurnal Pembaharuan Hukum, Volume II No. 2 Mei-August 2015, page.151-161

2 Natal Kristiono, Politik Hukum Pemberantasan Korupsi, Jurnal Pengabdian Hukum Indonesia, Vol. 4, No. 3, 2018, page. 968. 
trend of corruption crime from year to year has always been increasing. Based on data from The Corruption Eradication Commission's Annual Report, That Corruption Crimes From 2005 To 2017 Through The Hand-Catch Operation Action if accumulated have reached 77 cases of corruption and resulted in 241 suspects. $^{3}$ Furthermore, The Hand-Catch Operation Actions Carried Out By The Corruption Eradication Commission In 2018 have reached 30 actions and resulted in 121 suspects. Referring to the increase in the criminal act of corruption, of course it will systematically also have an impact on increasing the amount of state financial losses.

Data released from the Indonesian Corruption Watch (ICW) also states that the prosecution for corruption cases handled by the Attorney General's Office in 2018 amounted to 235 cases, with a value of state losses of 4.8 trillion, 3.4 billion from corruption through illegal fees, and as many as 732 million came from bribery corruption. Likewise, the police also experienced an increasing trend, which handled 162 cases, with a total loss of 425 billion in state finances, 3.3 billion from corruption in illegal collection, and as many as 906 million from bribery corruption. Furthermore, the Corruption Eradication Commission in 2018 also handled 57 cases with a value of 385 billion state losses, 91 billion from bribery corruption cases, and as many as 132 billion from money laundering corruption. ${ }^{4}$

In connection with this data, policy makers have also prepared various regulations to save state financial losses. In this context, in addition to the law stipulating the existence of basic crimes in the form of imprisonment and fines in each article, in other articles additional penalties have been prepared which aim to save state financial losses due to criminal acts of corruption. The provisions regarding additional penalties are regulated in Article 18 of Act No. 20 of 2001 concerning Amendments to Act No. 31 of 1999 concerning Eradication of Corruption Crime. In this Article it is explained that in addition to additional penalties as referred to in the Criminal Code, as an additional punishment is confiscation of movable property which is tangible or intangible or immovable property which is used for or obtained from the criminal act of corruption, including companies owned by the convict a criminal act of corruption is committed, as is the price of the goods that replace these goods. Payment of replacement money in the amount of the same as property obtained from the criminal act of corruption.

Based on such additional criminal provisions, it is unlikely that state financial losses cannot be saved. This is because the convicted person also has the obligation to provide replacement money to the state, in the amount of assets obtained through the proceeds of the criminal act of corruption. Furthermore, the state even has the legitimacy to confiscate the property of the defendant to cover the replacement money. It's just that, in practice in the field, efforts to recover state financial losses do not always go as

3 Annual Report of the Corruption Eradication Commission 2016 and 2017.

4 Puteri Hikmawati, Pengembalian Kerugian Keuangan Negara dari Pembayaran Uang Pengganti Tindak Pidana Korupsi , Dapatkah Optimal?, Jurnal Negara Hukum, Vol. 10, No.1, 2019, page. 91. 
desired, even these rescue efforts also often do not cover all state financial losses. This refers to Rustam's research which states that the West Sumatra High Court in 2011 handled 51 cases of corruption with an estimated total state financial loss of IDR 29,710,653,690.00 (twenty-nine billion seven hundred ten million six hundred fifty-three thousand six hundred and ninety rupiahs), while the state financial loss that was saved was only IDR 2,975,460,000.00 (two billion nine hundred seventy-five four hundred and sixty thousand rupiah). Furthermore, in the case of the Teluk Sirih PLTU project in 2010, the investigation team only saved state financial losses of IDR $1,100,000,000.00$ (one billion one hundred million rupiah), while the state financial loss is IDR $3,000,000,000.00$ (three billion rupiah). ${ }^{5}$

There is a total loss of state finances with the total saved as the data above, of course there has been an imbalance in the process of handling corruption, considering that there is an excessive difference. In connection with this, it is certainly very irrational, when there is a gap regarding the total loss of state finances and the results of the losses that have been saved. With the provision of compensation money in the criminal act of corruption, state financial losses should be able to be overcome, given that the state has strong legitimacy to control the convict's entire assets, so that it can cover the total amount of losses suffered by the state. In connection with this fact, the aim of this research is to examine more deeply what factors cause state financial losses in corruption, as well as what strategies must be taken to recover from state financial losses.

\section{B. RESEARCH METHODS}

The research method used in this research is library research. Mestika Zed defines library research as library research that utilizes library sources to obtain research data, so that library research limits its activities only to library collection materials. ${ }^{6}$ While the approach used in this research is normative juridical. In Soerjono Soekanto's view, normative juridical research is a series of legal research carried out by examining library materials or secondary data as the basic material to be researched by conducting a search of regulations and literature related to the problem under study. ${ }^{7}$

The legal materials used in this study consist of primary and secondary legal materials. Primary legal materials consist of statutory regulations, official records or treatises relating to this research. Meanwhile, secondary legal materials relate to legal materials that provide clarification to primary legal materials, such as books, literature, articles, papers and other materials taken from legal experts.

5 Rustam, Pelaksanaan Pengambilan Kerugian Keuangan Negara (Asset Recovery) Dalam Tindak Pidana Korupsi (Studi Kasus Kejaksaan Tinggi Sumatera Barat.), Dimensi, Vol. 6, No. 2, 2017, page. 212.

6 Mustika Zed, , Metodologi Penelitian Kepustakaan, Yayasan Obor Indonesia, Jakarta, 2008, page. 1-2.

7 Soerjono Soekanto dan Sri Mamudji, Penelitian Hukum Normatif (Suatu Tinjauan Singkat), Rajawali Pers, Jakarta, 2001, page. 13. 


\section{RESULT AND DISCUSSION}

\section{Law Enforcement Against Rescue of State Financial Losses in Corruption Crime}

The process of law enforcement, legal application, or law enforcement is the most important part of realizing the rule of law. Without a law enforcement process, order and tranquility will never be realized, so legal regulations are only words that have no meaning in life. ${ }^{8}$ According to Soerjono Soekanto, law enforcement is an activity to harmonize the relationship of values that are described in solid principles/views and embody attitudes as a series of final-stage value descriptions to create social engineering and maintain peace in social life. ${ }^{9}$ In line with that, Satjipto Rahardjo also emphasized that law enforcement is a process to turn legal desires into reality. What is meant by legal desires are the thoughts of a legislative body formulated in statutory regulations. ${ }^{10}$

Basically, law enforcement efforts are closely related to the substance of the law in the form of statutory regulations. In this context, laws and regulations relating to the crime of corruption were first regulated in the Military Authority Regulation dated 9 April 1957 Number Prt/PM/06/1957, dated 27 May 1957 number Prt/PM/03/1957, and the 1st. July 1957 Number Prt/PM/011/1957. The military rulers' regulations only apply temporarily and are replaced by Government Regulations in Lieu of Act No. 24 of 1960 concerning Prosecution, Prosecution and Corruption Crime Examination which was subsequently stipulated as Act No. 24 Prp of 1960 concerning Prosecution, Prosecution and Corruption Crime Investigation. Implementation of Act No. 24 Prp of 1960 concerning Corruption Criminal Investigation, Prosecution, and Corruption has not yet reached its maximum level, so 11 years later it was changed to Act No. 3 of 1971 concerning the Eradication of Corruption Crime. After Act No. 3 of 1971 concerning Corruption Eradication is valid for 28 years, so this law is no longer in accordance with the times, so the MPR stipulates MPR Decree No. XI/MPR 1998 which, among other things, stipulates that it should be further regulated by a law on efforts to eradicate corruption. Based on the MPR Decree No. XI/MPR in 1998, was enacted in 1999, so Act No. 28 of 1999. Subsequently on August 16,1999, Act No. 31 of 1999 as a substitute for Act No. 3 of 1971 which was declared invalid. Act No. 31 of 1999 was then made amendments to Act No. 20 of 2001 concerning amendments to Act No. 31 of 1999 concerning Corruption Eradication. It's just that, of the many laws, only Act No. 20 of 2001 concerning amendments to Act No. 31 of 1999 concerning Corruption Eradication which explicitly aims to

8 Titik Triwulan dan Ismu Gunadi Widodo, Hukum Tata Usaha Negara dan Hukum Acara Peradilan Tata Usaha Negara Indonesia, Kencana, Jakarta, 2011, page. 339.

9 Alimuddin Siregar, Regulasi Hukum Pornografi, Scopindo Media Pustaka, Surabaya, 2019, page. 95.

10 Y. Sri Pudyatmoko, Perizinan: Problem dan Upaya Pembenahan, Grasindo, Jakarta, 2009, page. 111. 
eradicate corruption crimes and save state financial losses. ${ }^{11}$ That is why one of the articles in this law contains additional penalties in the form of payment of replacement money. Although the provisions regarding additional penalties in the form of replacement money and the procedure for controlling the assets owned by the convicted person have been enforced, the total loss of state finances with the results that have been saved is in fact in some cases a significant difference.

In connection with this reality, regulations regarding replacement money and its implementation are as contained in Article 18 of Act No. 20 of 2001 concerning Amendments to Act No. 31 of 1999 concerning the Eradication of Corruption Crime is basically the right thing to do. This is because this regulation has given legitimacy to the state to control and take the property of the convicted person to cover the replacement money. However, the results of the saving of state financial losses are not absorbed due to the implementation of the handling of corruption crimes which still use the old pattern, namely by using the retributive justice approach. The doctrine of retributive justice comes from the thought of Lex Talios, which means that a person has the right to experience and reward in kind for what he does to others. Based on the thought of Lex Talios, the teaching of retributive justice emphasizes more on retaliation, so that the aim is to determine who is to blame, and what kind of punishment should be imposed on the wrongdoer. ${ }^{12}$

The use of a retributive justice approach by prioritizing repressive actions certainly requires a lot of money, especially when faced with proving a complicated corruption case. Based on the statistical data presented by Muhammad Jusuf, it is stated that the total state financial loss that was saved by the Corruption Eradication Commission in the 2009-2014 period was IDR 728,445,149,242, - (seven hundred twentyeight billion four hundred forty-five million one hundred forty-nine thousand two hundred forty-two rupiah), while the budget ceiling and expenditure realization required by the Corruption Eradication Commission during the period 2009-2014 amounted to IDR . $3,019,822,079,000.00$ (Three trillion nineteen billion eight hundred twenty-two million seventy-nine thousand rupiah). ${ }^{13}$ Based on these statistical data, there is a difference of around IDR 2,291,376,929,758.00 (two trillion two hundred ninety-one million three hundred seventy-six million nine hundred twenty-nine thousand seven hundred and fifty-eight rupiah). The difference does not include the cost of the case provided by the State Budget, with an average of IDR 250,000,000.00 (two hundred and fifty million) to IDR $500,000,000.00$ (five hundred million) per case

11 Nurul Aini, Analisis Yuridis Kebijakan Sanksi Pidana Pengembalian Kerugian Keuangan Negara Dalam Tindak Pidana Korupsi, Jurnal Bagian Hukum Pidana, Vol. 2, No. 3, 2014, page. 23.

12 Muhammad Yusni, Keadilan dan Pemberantasan Tindak Pidana Korupsi Perspektif Kejaksaan, Airlangga University Perss, Surabaya, 2020, page. 151.

13 Romli Atmasasmita, Rekonstruksi Asas Tiada Pidana Tanpa Kesalahan (Geen Straf Zonder Schuld), Gramedia Pustaka Utama, Jakarta, 2017, page. 34-35. 
to conduct investigation, investigation, pre-prosecution, prosecution and examination at trial. Furthermore, there were 5907 cases of corruption cases handled by the Attorney General's Office And The Corruption Eradication Commission In 2014. Of The 5,907 cases, the total estimated APBN funds used to handle corruption cases were around IDR $1,476,750,000,000.00$ (one trillion four hundred seventy-six billion seven hundred and fifty million). Even then, the estimate used is the smallest cost, which is IDR 250,000,000.00 (two hundred and fifty million rupiah) ${ }^{14}$

The figure for handling corruption crimes does not include the budget that must be prepared by the state to feed detainees in prisons. Say in a marketing agency there are 100,000 (one hundred thousand) people per year, at a cost of one inmate, say as much as IDR 15,000.00 (fifteen thousand rupiah), then the cost that must be incurred by the state to provide food per day is IDR $1,500,000,000.00$ (one billion five hundred million rupiah) or in the amount of IDR 547,500,000,000.00 (five hundred forty-seven billion five hundred million rupiah) per year. ${ }^{15}$ Regardless of this context, the existence of a correctional facility is basically intended to rehabilitate and socialize the perpetrators of crime. It's just that, the existence of a social institution like this also requires expensive costs, so that the state experiences more and more losses. Based on this fact, the regulation regarding replacement money and its implementation in Article 18 of Act No. 20 of 2001 concerning Amendments to Act No. 31 of 1999 concerning the Eradication of Corruption Crime is not the main problem regarding the unsaved of state financial losses. However, the stagnation of state financial losses is basically due to the law enforcement of corruption crimes which still prioritizes retributive justice with repressive efforts, so that it is increasingly detrimental to state finances.

\section{Strategy for Handling Corruption Crime in Relation to Rescue of State Financial Losses}

The strategy for handling corruption crimes as described above still prioritizes retributive justice with repressive efforts, so it requires a very high cost. The high cost of handling corruption crimes is certainly contrary to the principles of fast, simple, and low cost justice as adhered to by the Criminal Procedure Code and Act No. 48 of 2009 concerning Judicial Power. Based on Article 2 paragraph (2) of Act No. 48 of 2009 concerning Judicial Power states that justice is simply an examination and settlement of cases carried out in an effective and efficient manner. Furthermore, what is meant by low cost is the cost of the case required to settle the case within reach of the community. As for rapid justice is a

14 Ibid, page. 37-38.

15 Ibid, page. 42. 
judicial process that does not take long, long, and wordy within the framework of the criminal justice system. ${ }^{16}$

In line with this principle, adequate reformulation is needed in order to eradicate corruption to its roots. This is because in addition to handling corruption by using repressive channels, it costs a lot of money, a repressive approach like this will also result in a legal mirage. A legal mirage is an affirmation as if law enforcers have continuously enforced the law, but the goals that will be achieved through the incarnation of the law are getting away, because law enforcers are trapped in the realm of law and punishment. In connection with this fact, a strategy to handle corruption is needed so as not to overburden state financial losses. Efforts to eradicate corruption crimes should prioritize prevention, rather than prosecution. This preventive effort is important to do, considering that the Deputy Chairperson of the Corruption Eradication Commission, Lili Pantauli Siregar, stated that the tendency of perpetrators of corruption is basically due to motives, rationalizations that come from each individual and there are opportunities related to systems that have loopholes of corruption. With Lili Pantauli Siregar's view, prevention efforts against the occurrence of criminal acts of corruption are one of the strategic steps that need to be minimized, because preventive measures have a more significant impact on the surrounding environment. This is in line with the viewpoint of Herbert L. Peker, who said that prevention efforts against various criminal acts, including corruption, have a wider impact on the environment. ${ }^{17}$ Herbert L. Peker's view is quite reasonable because efforts to prevent criminal acts at the practical level will keep the state from being trapped in the realm of law and punishment through the courts. This statement at least will also restore the spirit of the court as the last remedy to seek justice (Ultimum Remidium). ${ }^{18}$

The other side of that, efforts to prevent criminal acts of corruption will also minimize losses to state finances as explained above. This is because the higher saving of state financial losses (through the Corruption Eradication Commission's enforcement function) actually has an impact on decreasing the absorption capacity of the APBN, so that the repressive law enforcement function has not been maximally successful, effective and efficient with the driving force of the national economy. The Coordinating Ministry for Economic Affairs, Andie Megantara in the 2016 launch of the book "Microeconomic Analysis of Indonesian Criminal Law" also stated that a rough calculation of every IDR 10 trillion capital expenditures that are not absorbed, will have an impact on the decline of $0.11 \%$ economic growth and every IDR 10 trillion expenditures for goods

16 Bambang Waluyo, Penyelesaian Perkara Pidana; Penerapan Keadilan Restoratife dan Transformatif, Sinar Grafika, Jakarta, 2020, page. 60.

17 Herbert L Pecker, The Limits of The Criminal Sanction, Stanford University Press, California, 1968, page. 35.

18 Jonaedi Efendi, Ismu Gunaedi Widodo, dan Fifit Fitri Lutfianingsih, Kamus Istilah Hukum Populer, Kencana, Jakarta, 2016, page. 406. 
and services that are not absorbed will have an impact on a $0.06 \%$ decline in economic growth, whereas the estimated calculation from the Coordinating Ministry also states that every $1 \%$ economic growth will absorb 250-350 thousand workers. ${ }^{19}$ Based on these data, law enforcement that is more oriented towards preventive action will be directly proportional to the improvement of the national economy. In addition, preventive measures for criminal acts of corruption will also better ensure that social justice is maintained, do not cause prolonged social impacts, and reduce the burden of state financial losses, so that social harmony can be maintained and closer to the ideals of the nation and state.

Efforts to prevent criminal acts of corruption should further improve the systems contained in the legislative, executive and judiciary institutions, both from the central government to the regions. This system improvement aims to close the gaps in criminal acts of corruption, so that there is no more opportunity to commit such acts. Furthermore, efforts to prevent criminal acts of corruption should also be accompanied by continuous and systematic auditing of all civil servants and state administrators, so that when there are unreasonable funds, they can be immediately detected and the civil servants or state administrators must prove that the funds are not of his corrupt acts.

With regard to such preventive measures, of course, repressive law enforcement is still needed. However, repressive law enforcement is the last resort, when other efforts to eradicate corruption cannot be done. The existence of repressive law enforcement in criminal acts of corruption also no longer uses basic criminal sanctions in the form of imprisonment or imprisonment. This is due to the imprisonment and imprisonment as discussed earlier, in fact it is increasingly burdening the state finances, so that the state experiences more losses. The criminal sanction for perpetrators of corruption should be a death sentence, so that such punishment does not burden state finances and can provide lessons for state administrators and society at large. In this context, there is still a lot of debate, especially for human rights activists who claim that the death penalty violates human rights. However, the statutory provisions in Indonesia still recognize the death penalty as a criminal sanction. Furthermore, the provisions regarding the death penalty have also been regulated in Article 2 paragraph (2) of Act No. 20 of 2001 concerning Amendments to Act No. 31 of 1999 concerning Eradication of Corruption Crime. This article explains that "In the event that the criminal act of corruption as referred to in paragraph (1) is committed under certain circumstances, the death penalty may be imposed. ${ }^{20}$ The explanation regarding certain conditions is a condition which can be used as an excuse for a criminal objection to the perpetrator of the crime against funds intended for handling dangerous

19 Romli Atmasasmita, Op.cit, page. 40-41.

20 Ridwan Zachrie dan Wijayanto, Korupsi Mengorupsi Indonesia, Gramedia Pustaka Utama, Jakarta, 2013, page. 678. 
situations, national natural disasters, overcoming the consequences of widespread social unrest, overcoming economic and monetary crises, and repeating acts corruption crime. ${ }^{21}$ In addition to the death penalty, criminal witnesses in the form of impoverishing corruptors as once voiced by Saldi Isra, Zainal Abidin Muchtar, and Bambang Widjojanto can also be used as an alternative to eradicate corruption in a repressive manner. The effort to impoverish this is because perpetrators of corruption are not afraid of imprisonment, because prisons can be bought, but perpetrators of corruption are definitely afraid of poverty.

\section{CONCLUSION.}

A more in-depth study of the factors that cause state financial losses in corruption, as well as strategies that must be taken to recover state financial losses in the provision of additional crimes in the form of replacement money as contained in Article 18 of Act No. 20 of 2001 Act No. 31 of 1999 concerning Eradication of Corruption Crimes is basically suitable to recover state financial losses. It's just that, there are additional crimes like this because they are accompanied by law enforcement with a retributive justice approach that prioritizes repressive actions, corruption eradication strategies should prioritize prevention rather than repressive law enforcement. In addition to prevention efforts against criminal acts of corruption will also minimize losses to state finances, prevention efforts will also better ensure the maintenance of social justice, and do not cause prolonged social impacts, so that social harmony can be maintained and get closer to the ideals of the nation and state.

\section{BIBLIOGRAPHY}

\section{Book:}

Alimuddin Siregar, 2019, Regulasi Hukum Pornografi, Scopindo Media Pustaka, Surabaya;

Bambang Waluyo, 2020, Penyelesaian Perkara Pidana; Penerapan Keadilan Restoratife dan Transformatif, Sinar Grafika, Jakarta;

Herbert L Pecker, 1968, The Limits of The Criminal Sanction, Stanford University Press, California;

Himpunan Peraturan Korupsi, Kolusi, dan Nepotisme (KKN) \& Hak Asasi Manusia, 2002, Penerbit Cv. Eko Jaya, Jakarta;

Jonaedi Efendi, Ismu Gunaedi Widodo, dan Fifit Fitri Lutfianingsih, 2016, Kamus Istilah Hukum Populer, Kencana, Jakarta;

21 Himpunan Peraturan Korupsi, Kolusi, dan Nepotisme (KKN) \& Hak Asasi Manusia, Penerbit Cv. Eko Jaya, Jakarta, 2002, page. 86. 
Muhammad Yusni, 2020, Keadilan dan Pemberantasan Tindak Pidana Korupsi Perspektif Kejaksaan, Airlangga University Perss, Surabaya;

Mustika Zed, 2008, Metodologi Penelitian Kepustakaan, Yayasan Obor Indonesia, Jakarta;

Annual Report of the Corruption Eradication Commission of 2016 and 2017.

Ridwan Zachrie dan Wijayanto, 2013, Korupsi Mengorupsi Indonesia, Gramedia Pustaka Utama, Jakarta;

Romli Atmasasmita, 2017, Rekonstruksi Asas Tiada Pidana Tanpa Kesalahan (Geen Straf Zonder Schuld), Gramedia Pustaka Utama, Jakarta;

Soerjono Soekanto dan Sri Mamudji, 2001, Penelitian Hukum Normatif (Suatu Tinjauan Singkat), Rajawali Pers, Jakarta;

Titik Triwulan dan Ismu Gunadi Widodo, 2011, Hukum Tata Usaha Negara dan Hukum Acara Peradilan Tata Usaha Negara Indonesia, Kencana, Jakarta;

Y. Sri Pudyatmoko, 2009, Perizinan: Problem dan Upaya Pembenahan, Grasindo, Jakarta;

\section{Journal:}

Jawade Hafidz, Agung Widodo, Pelanggaran Perpres Nomor 54 Tahun 2010 Tentang Pengadaan Barang Dan Jasa Pemerintah Oleh Penyedia Barang Dan Jasa Atau Pengguna Jasa Dalam Perspektif Tindak Pidana Korupsi, Jurnal Pembaharuan Hukum, Volume II No. 2 MeiAgustus 2015;

Natal Kristiono, Politik Hukum Pemberantasan Korupsi, Jurnal Pengabdian Hukum Indonesia, Vol. 4, No. 3, 2018;

Nurul Aini, Analisis Yuridis Kebijakan Sanksi Pidana Pengembalian Kerugian Keuangan Negara Dalam Tindak Pidana Korupsi, Jurnal Bagian Hukum Pidana, Vol. 2, No. 3, 2014;

Puteri Hikmawati, Pengembalian Kerugian Keuangan Negara dari Pembayaran Uang Pengganti Tindak Pidana Korupsi , Dapatkah Optimal?, Jurnal Negara Hukum, Vol. 10, No.1, 2019;

Rustam, Pelaksanaan Pengambilan Kerugian Keuangan Negara (Asset Recovery) Dalam Tindak Pidana Korupsi (Studi Kasus Kejaksaan Tinggi Sumatera Barat.),Dimensi, Vol. 6, No. 2, 2017; 